60 | july - august 2005

Varia

\title{
Taiwanese NGOs and HIV/Aids: From the National to the Transnational
}

\section{Vincent Rollet}

\section{Q OpenEdition}

12 Journals

Édition électronique

URL : http://journals.openedition.org/chinaperspectives/498

DOI : 10.4000/chinaperspectives.498

ISSN : 1996-4617

Éditeur

Centre d'étude français sur la Chine contemporaine

\section{Édition imprimée}

Date de publication : 1 août 2005

ISSN : 2070-3449

Référence électronique

Vincent Rollet, «Taiwanese NGOs and HIV/Aids: From the National to the Transnational », China Perspectives [En ligne], 60 I july - august 2005, mis en ligne le 01 juin 2008, consulté le 28 octobre 2019. URL : http://journals.openedition.org/chinaperspectives/498 ; DOI : 10.4000/chinaperspectives. 498

Ce document a été généré automatiquement le 28 octobre 2019.

(C) All rights reserved 


\title{
Taiwanese NGOs and HIV/Aids: From the National to the Transnational
}

\author{
Vincent Rollet
}

1 Published in July 2004, UNAIDS' most recent annual report on the human immunodeficiency virus (HIV)/ Acquired immunodeficiency syndrome (Aids) across the world does not hide the writers' anxiety about an epidemic that "continues to outpace the global response" 1 and that "in Asia is expanding rapidly" 2 Indeed, in this AsiaPacific region where at least 8.2 million children and adults are living with $\mathrm{HIV}^{3}$, the number of people infected with the virus is growing. This assessment is just as true for Taiwan, which is obviously not an island when it comes to infectious diseases. Thus, just as it was across the world, 2004 was a bleak year for Taiwan in its struggle against new infections. Indeed, despite the limitations of all statistical data on HIV/Aids, the figures going back to 1984, and provided by the Centre for Disease Control (CDC, Jibing guanzhi ju $)^{4}$, reveal that Taiwan had 1,562 new cases ${ }^{5}$ in 2004, the highest figure ever recorded there (see Table 1). While today ${ }^{6}$, with 9,229 cases $\left(0.040 \%\right.$ of its population ${ }^{7}$ ), Taiwan is not the worst affected country in Asia, Taiwanese experts are worried about the growing proportion of infections among young people between 14 and 25 (50\% of the total in 2004). What is worse, they are unsure how accurate the HIV/Aids statistics are, distorted as they are by people's fears about Aids screening and the social consequences of divulging their serological status.

Without denying or belittling the official Taiwanese response to HIV/Aids, it is useful to consider two social phenomena dating from the same period, the late 1980s and early 1990s: the increase in the number of HIV/Aids cases, on the one hand, and the rapid growth in the number of civil associations, on the other. Taking these two developments together encourages us to concentrate on the role of some specific organisations in combating the disease. To this end, after a short historical introduction to these organisations, we will focus on their functioning as well as on their everyday work to see the typology of this space in the Taiwanese associative 
world. Later we will consider the relations between these organisations and the Taiwanese health authorities to show their diversity and what effects they have had. Lastly, we shall look into the transnational activity of some of these organisations across the Asia-Pacific region.

Taiwanese organisations fighting HIV/Aids: how they emerged, how they functionThe conditions under which they first appeared

The abolition of martial law in 1987 and economic prosperity are two factors key in explaining the island's "associative revolution", which is characterised by the rapid growth in the number of civil associations. This does not mean that no associations existed before, quite the contrary. But under martial law, the Kuomintang's practice of co-opting social forces, described by some as "mobilisational authoritarianism", had made the development of "non-traditional NGOs"10 almost impossible. In this new, favourable situation and in response to the growing number of cases of infection by the HIV virus, rapid growth occurred in the early 1990s in the number of associations dedicated to fighting HIV/Aids. Some were generated from the discussions of a group composed of people living with HIV/Aids and health professionals-Light of Friendship AIDS Control Association of Taiwan (Lofaa), Persons with HIV/AIDS Rights Advocacy Association (PRAA), Living with Hope Organization, Collective of Sexworkers and Supporters (Coswas). Others grew out of foundations wishing to diversify their interests-Students Against Aids, Garden of Mercy Foundation-out of the initiative of a former member of the government-Taiwan Aids Society (TAS) - out of a religious organisation deciding to re-focus its mission-Lourdes Home ${ }^{11}-$ or again out of the government's wish to widen the national application of associative action-Aids Care Association. Lastly, some organisations were born of the requirement to register in order to apply for financial support grants from the government-Harmony Home Association-or of internal tensions caused by the need to prioritise the fight against HIV/Aids-Taiwan Love and Hope Association.

\section{New cases of HIV/AIDS registered annually in Taiwan}

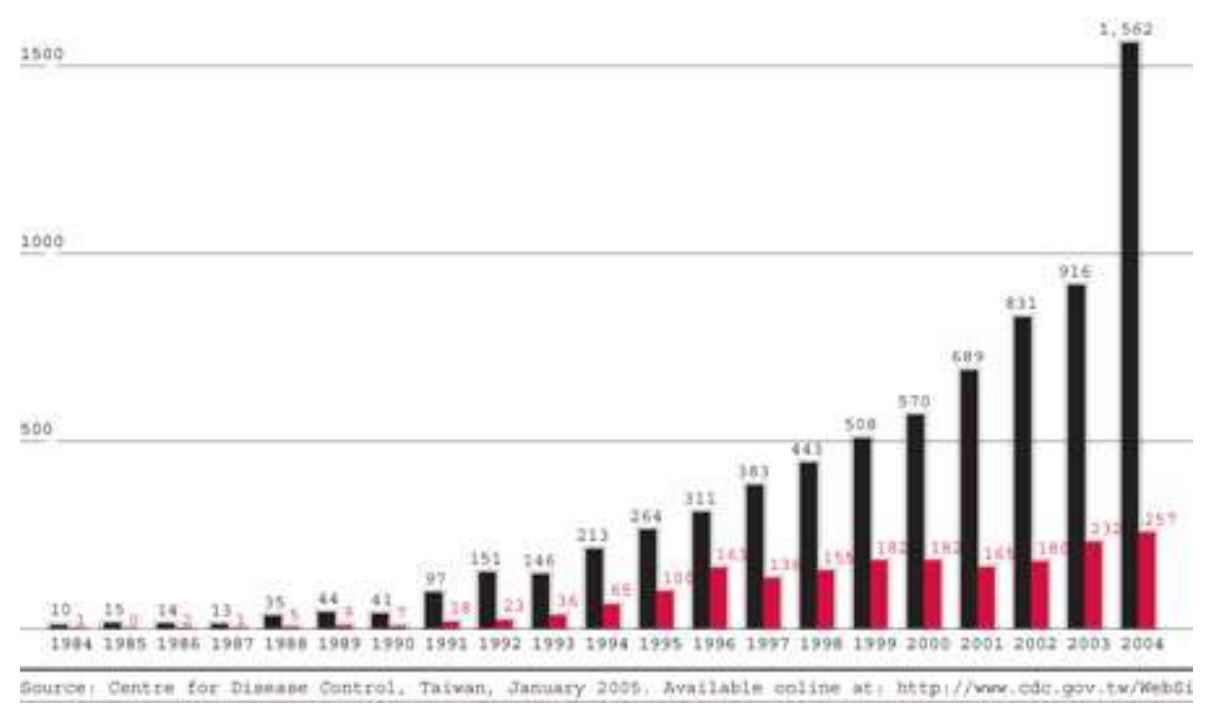

Counting only the officially registered organisations, there are today in Taiwan about twenty associations (xiehui), foundations (jijinhui) and institutes (xuehui) engaged in activities relating to HIV/Aids. Among them, 11 have made the fight against HIV/Aids their primary concern (see Table 2). These will be the main object of our attention. 
2. The emergence of organisationd fighting HIV/Aids in Taiwan : a chronology

\begin{tabular}{|c|c|c|}
\hline \multicolumn{2}{|c|}{$\begin{array}{l}\text { Year of Usual name } \\
\text { formationin Inglishl }\end{array}$} & \multirow{2}{*}{$\begin{array}{l}\text { Area } 0 \\
\text { activi } \\
\text { Taipel }\end{array}$} \\
\hline 1992 & $\begin{array}{l}\text { Light of Friendship ADS Control } \\
\text { Association of Talwan (LOFAA) (i) }\end{array}$ & \\
\hline 1992 & Taiwan AIDS Society (TAS) (2) & Taipei \\
\hline 1992 & Students against AIDS $(x)$ & Taipel \\
\hline 1993 & Living with Hope Organization (4) & Taipei \\
\hline 1997 & Lourdes Home (5) & Taipel / Taichung \\
\hline 1997 & $\begin{array}{l}\text { Persons with HIV/AIDS Rights } \\
\text { Advocacy Association (PRAA) }\end{array}$ & Taipel \\
\hline 1999 & Alos Care Association (7) & Taichung \\
\hline 1999 & Taiwan Love and Hope Association (क) & Kaoshiung \\
\hline 1999 & $\begin{array}{l}\text { Collective of Sexworkers } \\
\text { and Supporters (COSwAS) igs }\end{array}$ & Taipei \\
\hline 1999 & Garden of Mercy Foundation (TO) & Taipei \\
\hline 2003 & Harmoay Home Association (i) & Taipei \\
\hline \multicolumn{3}{|c|}{ 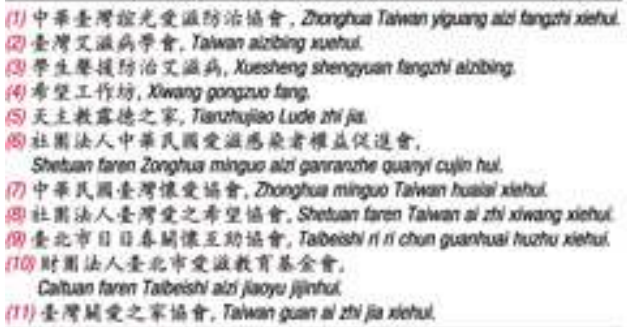 } \\
\hline
\end{tabular}

Organisational maturity and lasting financial stability

5 Most of these organisations are small structures each employing somewhere between three and six staff with precise responsibilities mentioned in the official documents of the organisation. The leadership rarely changes, which guarantees some permanency to the projects undertaken. Of the 11 organisations studied, eight are led by women. Alongside them are volunteers (students, people living with HIV, retired people) who, after some training, help with day-to-day tasks. However, as some members say, recruiting volunteers is not always easy, especially because candidates or their families are apprehensive due to widespread views and beliefs surrounding the disease.

Their budgets, from what we know of them ${ }^{12}$, vary between NT\$1.5 million and NT\$6 million (from US $\$ 45,000$ to US $\$ 190,000$ ) and grow steadily, although national economic conditions do not particularly favour the non-profit-making sector.

7 Sources of funding vary widely. Together with private donations, which are often a vital contribution, the organisations can count on sales of their own products (gadgets, T-shirts, flowers), support from the Department of Health and from the United Way Taiwan foundation ${ }^{13}$. The latter gives substantial financial help after examining the association's plans and provided that its criteria for good management are satisfiedcriteria such as transparency, efficiency, responsibility and capacity for self-evaluation. These demands are gradually being imposed, it seems, right across Taiwan's non-profitmaking sector and, accordingly, on organisations fighting Aids: organisations, in exchange for funding from this silent partner, commit themselves to respecting these rules.

8 In recent years, Taiwan's associative sector, whose rapid development has been compared to "bamboo shoots growing after rain" ${ }^{14}$, has frequently been criticised for 
its excessive number of "family NGOs"15 consisting of one member, or perhaps two, whose aims, structure and funding remain unclear. This situation, in many respects, dries up the flow of funding and support, which also harms the better-structured organisations. Unlike these "mini-NGOs", Taiwan's organisations for combating HIV/ Aids have reached a certain degree of maturity in their structures by carrying out fieldwork over a period-sometimes discontinued-lasting at least six years in most cases $^{16}$. This period may seem short when set alongside foreign experience, but it is substantial by Taiwanese standards, given the very recent development of the whole sector. Moreover, with a few exceptions, these organisations have achieved lasting financial stability, essential for effective activity. Even so, the search for funding remains vitally important in terms both of their survival and of the time devoted to it.

Lastly, when we look at their geographic location, we find a serious imbalance between the north, the centre and the south of the island. Indeed, while the north-mainly Taipei-is home to eight of the eleven organisations, only two are based in Taichung and one in Kaohsiung, two regions where the number of HIV/Aids cases have sharply increased: over the past two years, the increase in the number of carriers in these two cities and their regions (xian) is put at $48.6 \%$ and $49.1 \%$ respectively. This growth rate is higher than in Taipei and its xian, which over the same period has recorded a growth of $43.2 \%$ in the numbers of new infections.

The absence of organised activity in southern Taiwan, in the fight against HIV/Aids, seems to derive from several factors. Firstly, the numbers of HIV-positive cases were until recently more significant in the north, especially in the capital, hence the initial location of the organisations. Furthermore, the various sources of financial backing are based in Taipei; and it is there that personal relations between the fund-raisers and their backers can quickly be established and maintained. To sum up, it seems clear that, for reasons both financial and psychological, few of those organisations working in Taipei have the capacity for simultaneous activity in other regions.

One is obliged to note that this imbalance may be deleterious to the organisations' effectiveness. Thus, being aware that the campaign against HIV makes no sense unless it is waged on a national scale, some organisations are taking action where necessary in the south and in the islands close to Taiwan (such as Penghu and Ludao). However, such activity is still irregular.

A war on four fronts

12 The activities undertaken by the Taiwanese organisations correspond, directly or indirectly, to the four essential fronts in the war against HIV/Aids: prevention/ education, healthcare/social security, protection for people living with the virus and research/treatment. Careful analysis helps us to appreciate the diversity of these activities: what practical form do they take, and what kind of discourse do they pass on to the public?

Prevention and education

13 Ten of the eleven organisations have opted to devote themselves to prevention, directing their message in particular towards young people. This choice is justified both by the rapid spread of HIV infection among young people and by a failure in terms of initiatives in this field-a criticism made during an international conference held last July in Taipei ${ }^{17}$. At the same time, some organisations are focussing on more specific communities among young people, such as homosexuals, people taking drugs intravenously (Lourdes Home, Living with Hope) or sex workers (Coswas). 

colleges, secondary schools and universities with their support. A frequent approach is to give mass presentations in lecture halls, where videos, celebrities, emotionally moving personal accounts and sometimes actual tears ${ }^{18}$ are all employed to raise young people's awareness of a subject that most organisations try not to broach too directly ${ }^{19}$. Another approach to students consists of competitions, for the production of posters or short films about HIV/Aids, as organised by Students Against Aids, the winners being rewarded with prizes worth NT $\$ 80,000$ (US $\$ 2,500$ ). These posters are used later during public awareness campaigns. The fact remains that it is not unusual for educational establishments to refuse to host these sorts of activities, in particular private schools who "cannot understand why their pupils would have Aids" 20 fear of exposure to the police intensifies their sense of public ostracism and thus their inaccessibility to information efforts. However, some organisations are attempting through gradual approaches and the steady build-up of confidence to pass on the preventive discourse, hoping that by word of mouth the message will be spread more widely.

Working with homosexuals requires presentations in nightclubs, where the organisations offer information about the virus and the importance of using condoms, anonymous screening methods and warnings about the risks involved in re-using syringes.

Organisations doing prevention work with prostitutes find themselves in an unlikely situation. While their work is mainly concentrated on supplying information and condoms, its effectiveness is limited by the criminalisation of prostitution in Taiwan. Indeed, when the police make raids, they frequently seize upon used condoms as overwhelming proof of guilt, in order to impose heavy fines and/or temporary imprisonment on the sexworkers. This situation, caused by a law that is shortly to be reformed, is the main obstacle encountered on a daily basis by organisations such as Coswas. However, it is astonishing that, while some organisations do campaign for prostitution to be decriminalised, the question of stopping this particular activitywith the social reintegration that would result-is hardly ever mentioned. Yet, this reform would be an essential element in providing an effective response to HIV/Aids.

Lastly, some organisations also offer prevention and awareness services aimed at a wider public, at stations or during "patchwork of memories" exhibitions ${ }^{21}$. Their purpose is to overcome the obstacle-in Taiwan as everywhere else in the world-of groups perceived as being "at risk" being stigmatised; it is also to remind people that HIV/Aids infection is an issue affecting everyone and is never to be seen as the consequence of immorality.

19 The message put across by these prevention activities tends to develop along the lines of the $\mathrm{ABC}^{22}$ policy (Abstinence, Be faithful and Condom) as recommended by the Health authorities, who prescribe with varying enthusiasm all three forms of protection. Thus, while some organisations (TAS, Garden of Mercy) weight their prevention discourse mainly towards abstinence and fidelity, leaving the condom as the last resort, others (PRAA, Living with Hope) are far more critical of this strategy. In their eyes ${ }^{23}$, this approach is too closely inspired and legitimised by American programmes promoting abstinence: programmes directed by, among others, religious organisations supported ideologically and financially by the President's Emergency 
Plan for Aids Relief (PEPFAR) ${ }^{24}$. So the Taiwanese organisations reverse the order of priority, starting with the use of condoms and the importance of screening, while warning people not to rely on the other two prescriptions-abstinence and fidelity.

Treatment and social security

On the healthcare and social security front, two types of activities are undertaken. For some organisations (Lourdes Home, Garden of Mercy), the main activity is visiting the sick, at home, in hospital or in prison, to care for them and bring them moral support. It is intended as the remedy for discrimination. Thus, in prison, inmates who are HIVpositive and barely informed about the consequences, are often separated from other prisoners, neglected and thus doubly punished. Those living at home find themselves particularly alone when their family and friends stay away once their state of health becomes known. Lastly, in hospitals, where some care staff do not want to work with HIV-positive patients, organisations are called in by the hospital authorities ${ }^{25}$.

21 Another form of help consists of offering accommodation to HIV-positive patients, be it short-term (three months maximum for Lourdes Home) or medium- and long-term (Garden of Mercy, Harmony Home). These services are offered at the same time to people living with HIV/Aids who are out of hospital but still too weak to care for themselves, to patients in the last stages of the disease, to those with financial problems, to people visiting the capital city for treatment, and even-just recently-to young children whose HIV-positive parents are in difficulties ${ }^{26}$. The whereabouts of such accommodation is kept secret to avoid encountering opposition from neighbours fearful that their house values might depreciate ${ }^{27}$.

Support for those who are HIV-positive

Support for those who are HIV-positive, provided by organisations combating HIV/Aids in Taiwan, takes firstly the form of case by case support for victims of discrimination within the educational system, the army, industry, prison or public administration, after their HIV status becomes known. Since 1997, more than 145 requests for this form of help have been received, particularly by PRAA.

Problems with this support are nevertheless considerable. The Aids Prevention and Control Act (houtian mianyi quefa zhenghou qun fangzhi tiaoli) was passed in December 1990 to set the legal basis for control and prevention ${ }^{28}$. Its Article 6-1 lays down that "HIV-infected individuals shall not be discriminated against, nor shall they be deprived of their rights". However, at the same time, the "Control of Infectious Diseases Act, inherited from 1944 during the period of Japanese occupation ${ }^{29}$, leaves the door open to practices like isolation (art. 35) and defamation (art. 40), which may be used as legal weapons in the fight against activists. This law provides an ideal defence for some institutions which, bolstered by various specious arguments, are happy to cite it in support for their discriminatory words and deeds ${ }^{30}$. Thus in several respects, this latter Act is the sworn enemy of organisations fighting to support HIV patients.

Added to this legal paradox, brought about by contradictory texts, is the patients' fear of the social consequences of public exposure arising from legal action. Such factors are a strong disincentive when they consider asking for help or going to the law.

In a further legal attack, Article 14 of the 1990 Act "orders" foreign HIV-positive patients to "leave the country" ${ }^{31}$ and forbids such people to enter Taiwan ${ }^{32}$. While in November 2004 the government did propose relaxing this article, thus allowing foreigners who are HIV-positive to remain in Taiwan for up to 14 days $^{33}$, this decision merely exposed the official vagueness about how the virus is transmitted, and did 
nothing to improve the intolerable situation for men and women with families in the country. It is true that Taiwan is not the only state to apply this kind of legal restriction, seeing that the United States, Norway, Uzbekistan and Thailand all impose, with variations, similar measures.

Thus, the task of providing legal support for people who are HIV-positive, which some organisations undertake, must confront a real legal imbalance between the discriminators and those discriminated against ${ }^{34}$.

Lastly, the defence of people living with HIV also takes on a cross-sectoral form, as diverse organisations of Taiwanese civil society are brought together in opposition to a situation they deem intolerable. Such was the case when, in January 2004, the digital health insurance card came into force across the island. Opposition, to which we shall return later, was based on the assertion that this card contained personal information that might encourage discrimination against HIV-positive patients.

The link with the research world

The connections between scientific researchers, Taiwanese organisations and HIVpositive patients seem to operate primarily through the websites of the organisations fighting against HIV/Aids: it is there that information is published on treatments and new advances, as well as the results of studies and clinical trials carried out abroad. Such information comes mainly from foreign scientific reviews (mainly Englishlanguage journals), for which some organisations have been granted free translation rights. In addition, physical links have been created, some organisations being in direct contact with scientific circles; in some cases, their leaders are themselves scientists (Living with Hope), and in others they belong to wider structures devoted in part to research (TAS).

Typological essay: four organisational models

29 The war against HIV/Aids and its social consequences in Taiwan has mobilised organisations that, while sharing the same ultimate purposes, can be distinguished by their actions.

30 To make sense of this landscape, our first typology is based on two selection criteria: on the one hand, the activities most commonly cited in the organisations' internal documents or in interviews and, on the other, the activities accounting for a significant share of their expenditure. Hence, we have two categories divided each into two submodels (see Table 3). The first category is that of the organisations that specialise, and that involve themselves only on one front of the war against the virus. Within it, we can identify two organisational models. Firstly, there are the three organisations that devote their main activity to prevention. Next, there is the organisation-only one exists at present in Taiwan-whose main mission is to protect the rights of people who are HIV-positive.

31 The second category is that of organisations specialising in two fronts of the war. On the one side, there are the prevention and services organisations; in Taiwan, this is the most common organisational model, and five or six of the organisations studied belong to it. Next, there are the two prevention and research organisations, directly connected by their organisational structure to the world of scientific research.

of course, these separate models are far from being watertight. Thus, a prevention and services organisation may take on the role of advocate in a case of discrimination; and a 
legal support organisation may find itself involved in prevention. Even so, these represent only additional activities.

Based on this typology, three early conclusions suggest themselves. Firstly, these organisations have a more holistic approach than the medical/preventative approach, which is generally still predominant, especially in health institutions (medical research, epidemiological monitoring, tritherapy, public prevention). This is explained by their technical inability to involve themselves in research or epidemiological monitoring, and also because the distribution of antiretroviral drugs, which have been available free since 1997, can be undertaken only by specialised medical institutions.

This approach is the result also of choice, since these organisations generally seek to adhere to the health model known as "primary health care" ${ }^{35}$. Multidirectional prevention is thus the basis of their work, and the response to structural violence (discrimination, social disintegration) is its primary activity.

Then, there seems to exist among these organisations a real division between health work and prevention activity, which means that they do not cross-check their activities in the same areas or at the addresses of the same people. This division renders medium or long-term cooperation almost non-existent. Only a few holiday activities, trips abroad and some gatherings require short-term co-operation. Moreover, this reality lends renewed urgency to the idea of an "Alliance of Taiwanese NGOs in the War Against HIV/Aids", as recommended by the $\mathrm{CDC}^{36}$, an idea that some senior officials and most association members consider premature. Lastly, this division is exacerbated by undisguised competition in the hunt for grants, each organisation advertising its special merits to the funding authorities, which leads not infrequently to interpersonal tensions and a certain chauvinism among rival organisations ${ }^{37}$.

Looking beyond the state/society dichotomy

To appreciate the relationships that these organisations maintain with the health authorities, one must look beyond the conflict theory followed by many studies of civil society, a theory that places society's actors in opposition to the state. This dichotomy does not do justice to the "subtle and delicate" (WW, weimiao) relationship described to us by one Taiwanese association member ${ }^{38}$. In our search for an alternative approach, a bifocal study turns out to be revealing: we look at the interpersonal relations between these organisations and the official bodies, alongside the official support, both financial and material, provided for the various associative programmes. Three relationships: complementary, collaborative and oppositional

In light of this empirical study and with reference to the general classification of relations between the NGOs and the state proposed by Dennis Young ${ }^{39}$, we may identify three sorts of relationships between the Taiwanese organisations and the health authorities: complementary, collaborative and oppositional.

In the case of complementary relationships, the organisations are seen as "fulfilling the demand for public goods left unsatisfied by government" ${ }^{40}$. As regards the fight against HIV/Aids in Taiwan, we are considering here the types of relationships of most of the organisations, whether they are concerned with prevention, prevention/services or prevention/research. We are also considering a complex relationship taking diverse forms. It is based firstly on a more holistic approach, enabling it to act where the authorities cannot or will not involve themselves. Further, it is characterised by the organisations' participation in some activities of the Department of Health or the CDC, as well as by the physical presence of organisation leaders as observers in official 
institutions such as the Department of Health, the prison administration or the Ministry of Education. The relationship is expressed also in state financial support, which amounts to between $15 \%$ and $25 \%$ of the organisations' resources, even though this funding is still irregular and depends on whether the organisations' projects are in tune with the national health policy (thus, it is known that, while prevention programmes are well received, programmes offering services are less so). Lastly, relations between the leaders on both sides are often friendly.

In the context of collaborative relationships, the organisation is the partner of the government, which helps to deliver the service and, in the main, finances $\mathrm{it}^{41}$. Particular examples are Lofaa (funded mainly by the government), and the Taiwan Aids Society (headed by the former Department of Health director Twu Shiing-Jer), which works hand in hand with the health authorities ${ }^{42}$. These two types of relationships, complementary and collaborative, contribute to the collective management of health problems in Taiwan ${ }^{43}$.

When we come to oppositional relationships, the organisations "prod government to make changes in public policy and to maintain accountability to the public" ${ }^{44}$. This is mainly true of the advocacy organisation PRAA, which presents itself as very critical of policies on HIV/Aids. Its role is made possible by its minimal financial dependence on the health authorities ( $8 \%$ of its resources). In recent years, this opposition has taken various forms. Usually, the criticisms are expressed in its own review Quan (PRAA Taiwan Rights Journal), in newspaper articles or at press conferences, as was the case recently during World Aids Day, December 1st 2004, when subjects such as the rights of entry of HIV-positive foreigners and police pressure on people living with HIV were raised.

41 In addition, an "Alliance for the Protection of Personal Information" has been formed, PRAA joining with other organisations in Taiwanese civil society to prevent personal medical records from being included in the new digital health insurance card, launched by the Department of Health in January 2004. In the Alliance's view, this situation increases both HIV-positive patients' fear of having their status publicly disclosed and the discrimination against them within medical institutions ${ }^{45}$. A further example of this opposition is the setting up of an alternative forum on HIV/Aids, bringing together organisations and HIV-positive people, in response to the international conference organised by the CDC and the Health Department in Taipei in July 2004 ${ }^{46}$. These critical actions have led to an uneasy relationship between PRAA and senior health officials.

How much influence?

Organisations maintaining complementary relationships with the health authorities seem to exert greater influence over them. Thus, Lourdes Home, after several years of applying pressure on various authorities, has succeeded in setting up a system of support and information for intravenous drug-users in prison and training for prison officers ${ }^{47}$. We should mention also the work of Living with Hope devoted to promoting the free supply of HIV tests for pregnant women in the north of the island, in Taoyuan; since January this year, their work has been supported by the CDC on a national scale ${ }^{48}$. Lastly, the promotion of condoms, now publicly supported by the Department of Health $^{49}$, seems also to a great extent to be the result of work by organisations fighting against HIV/Aids and maintaining these kinds of relationships.

When it comes to the organisations with collaborative relations with the authorities, their margin for manoeuvre is restricted and their influence is either slight or 
dependant on a single personality, such as the head of TAS - who, all the same, would not envisage any departure from government policy on HIV/Aids.

Lastly, the only advocacy organisation, PRAA, exerts relatively little influence over the authorities. This situation is directly linked to the sensitive nature of the questions that it handles. For example, the question of reforming the present restrictions on HIVpositive foreigners entering Taiwan has been raised by the Department of $\mathrm{Health}^{50}$, but PRAA judges the results so far to have been inappropriate and unsatisfactory. As for the digital health insurance card, renewed last January, PRAA's demands relating to the information included were ignored.

In addition to assessing the influence that these organisations exert over the authorities, it is essential to look at the reverse process to create a dynamic picture. As regards the war against HIV/Aids, the health authorities obviously do seek to influence the organisation of civil society, particularly in the area of co-operation between the various associations. In recent years, all the moves towards large-scale co-operation have been initiated by members or ex-members of the Department of Health seeking to reduce competition between organisations. An early initiative was to set up an "umbrella NGO", named the "Red Ribbon Foundation", which, based on the American model of Aids Action ${ }^{51}$, was intended to group together all the Taiwanese organisations fighting against HIV/Aids. This initiative, launched by Twu Shiing-Jer, has had a chilly reception among the organisations. They criticise the project's lack of clarity, fearing to lose their autonomy.

A second initiative preceded the international conference on Aids held in Bangkok in July 2004. Those organisations wishing to take part were seeking financial help from the government. A few weeks beforehand, the same ex-minister and senior health officials imposed the condition that they must join the new "Alliance of Taiwanese NGOs fighting against HIV/Aids". So it was under the banner of this ad hoc alliance that they attended the conference.

Briefly, three conclusions suggest themselves. Firstly, as regards the war against HIV/ Aids, we are far from witnessing a state-versus-society dichotomy. On the contrary, there is only one organisation that clearly adopts an oppositional relationship. Secondly, the majority of the organisations (nine out of eleven) have sufficient autonomy to declare themselves "non-governmental". Thirdly, the influence exerted between the organisations and the health authorities is reciprocal.

Transnational health influences

Moving on from the national context of the fight against HIV/Aids, we should now look at the regional level and at transnational relations ${ }^{52}$. The regional and international levels are often perceived as spaces where NGOs working for people living with HIV/ Aids are active "both at the level of challenging certain (medical) practices and in the defence of individuals' rights"53. These are favoured areas for the exchange of information and ideas and for creating alliances that, in the long term, may help to strengthen the actions and the influence of NGOs locally ${ }^{54}$.

In his last book, the specialist in Taiwanese foreign policy Chen Jie considers that "the role of the Taiwanese NGOs on the international scene has been distorted, in quantity as much as in quality, by Taiwan's diplomatic isolation within the international community" 55 . For Taiwanese NGOs to play a role on the international stage is indeed made more difficult by Taiwan's exclusion from the UN, as well as by Chinese pressure, exerted on countries organising international conferences, to keep Taiwanese delegates 
from attending or, when they are present, to prevent the very word "Taiwan" from being used to designate their place of origin ${ }^{56}$. This situation is paradoxical for those who, naturally enough, are uninformed as to the diplomatic interests of foreign states but are dependent on them for their activities abroad ${ }^{57}$. Chen Jie concludes that the vulnerability of the Taiwanese NGOs to Taiwan's status within the international community explains their low profile in the region. While this situation is a reality across many sectors, it becomes indispensable when we look at the war against HIV/ Aids to take a more detailed approach.

The use of transnational health networks

It may be admitted that, despite the opening up of the international health space ${ }^{58}$ among non-state actors ${ }^{59}$, Taiwan has been placed since 1971 in a situation of "health apartheid"60; this has prevented its national NGOs from making themselves heard or winning support. But it is useful for us, when considering HIV/Aids, to direct our attention to another health space, namely, the transnational networks fighting against the virus. The Asia-Pacific region has a number of them, including a coalition generally known as "the Seven Sisters" that combines seven regional networks fighting against HIV/Aids ${ }^{61}$. Among those most closely linked to Taiwanese organisations, we shall look at the Asia-Pacific Network of People Living with HIV/Aids (APN+) and at Therapeutics Research, Education, AIDS Training in Asia (Treat Asia).

APN+ was formed in February 1994 and belongs to the Global Network of People Living with HIV/Aids (GNP+). It is a network of people, mostly HIV-positive patients, in the Asia-Pacific region. Its primary mission is to encourage such patients to involve themselves at every level in the war against HIV/Aids (Great Involvement of PWA, GIPA). To that end it provides assistance and advice to local associations of HIV-positive people, in the form of training programmes, exchanges of information, the organisation of conferences, and even help with fund-raising activities. Treat Asia, focused on medical research, was formed in 2001 by the American Foundation for Aids Research (amFAR) in response to the rapid growth in the number of HIV/Aids cases in Asia. Unlike APN+, its members are mainly health professionals seeking to strengthen the partnership between research circles and people living with HIV.

These more or less structured spaces have turned out to provide valuable exchanges and practical help for some Taiwanese associations. Thus, Living with Hope is in permanent contact via the Aids Research Centre of Yang-Ming University with the Treat Asia network, which has made the Centre one of its reference sites in Taiwan ${ }^{62}$. PRAA, Lourdes Home, the Aids Care Association and Harmony Home are in more or less regular contact with APN+.

These transnational spaces, and in particular their websites, are used in different ways by the Taiwanese associations. They provide daily access to up-to-date information on HIV/Aids (treatments, legal developments, epidemiological situation) ${ }^{63}$. In addition, they improve the regional visibility of Taiwanese campaigners against the virus, as was recently the case with the head of Living with Hope, to whom Treat Asia devoted a page of its website in October $2004^{64}$. The online forums run by these networks (SEA-AIDS Forum, PWHA-NET) are also perceived by Taiwanese organisations as an important influence on national policies relating to HIV/Aids. That idea was taken up by PRAA and the Aids Care Association who used them in December 2001 and August 2002 to publicise two petitions demanding that the Taiwanese government should revise its discriminatory policy towards HIV-positive foreigners ${ }^{65}$. 

HIV-positive people with accommodation and provides financial help for families reduced to extreme poverty as a result of their HIV status. In addition, it looks after orphanages for children whose parents have died of Aids: in four different places, Harmony is looking after more than a hundred orphans, providing them with food and education. In Guangdong, Harmony helps sick people with accommodation, takes them 
for treatment in hospital and arranges free drug treatment for them at certain hospitals.

Lourdes Home works in Xian (Shaanxi) and in Shenyang (Liaoning) in tandem with diocesan service centres run by the China Patriotic Church. Its leader and some of its social workers give training to the priests on Aids-related questions. They also help to set up centres for treatment and training, and arrange for the Chinese health workers to visit Taiwan to share experiences and to learn about the local Taiwanese situation ${ }^{72}$.

These activities are made possible, we should emphasise, not by long-distance aid but by maintaining a physical presence in China, thanks to several factors. Firstly, a key role is played by contacts abroad via transnational networks or informal encounters during international conferences. On this subject, tracing the careers of individual people can provide valuable insights. For instance, the head of Lourdes Home was educated in the United Kingdom and has kept numerous contacts there; the head of Harmony Home spent a year travelling to acquire experience abroad and to meet local workers in the fight against HIV/Aids. Thanks to such contacts, both these Taiwanese organisations were invited to China by international NGOs already established there and/or by local churches. Lourdes Home and Harmony were invited, respectively, by Misereor $^{73}$ and Médecins Sans Frontières (MSF), and also by priests and nuns wishing to take action against the spread of HIV/Aids in their dioceses.

The Taiwanese organisations working in China are there with the over-arching purpose of forming a confidence-based relationship: Taiwanese leaders say this is the essential preliminary to empowering local people (non-officials or even officials) eventually to carry on the war against HIV/Aids.

Lastly, we come to the shared feature of these projects, which is the secrecy surrounding them. Indeed, given the political situation across the Strait and the sensitive nature of any foreign intervention in China, particularly at the health level ${ }^{74}$, the projects were originally set up in conditions of absolute secrecy. In the case of Harmony, its director has lost count of her clandestine travels across rural China seeking to contact HIV-positive volunteers to help with her organisation's projects. Today, the work undertaken by the Taiwanese organisations is sometimes reported in the Taiwanese and Chinese media. Even so, its public profile remains low and could readily be kept lower still, in the interests of the people involved.

These forays into China do, however, encounter some obstacles. The most recent example arose as the consequence of a televised report about Harmony's work in Henan. The local administration, furious at being perceived as inactive, decided to close down one of Harmony's orphanages, moving the children on at once to an official orphanage built in 18 days and now under its own responsibility ${ }^{75}$.

Thus, the Taiwanese presence on the transnational scene of the fight against HIV/Aids is a reality. The simmering tensions over sovereignty on both sides of the Strait are not an insuperable obstacle. Sino-Taiwanese co-operation over HIV/Aids is based upon the commitment and the shared efforts of Taiwanese (the NGO staff) and Chinese (HIVpositive patients and health professionals) alike. The real problems are discrimination and the slow acknowledgement of the epidemic by some of the Chinese local administrations. Lastly, the ability of the Taiwanese NGOs to challenge certain practices and to support HIV-positive patients is now recognised by other transnational bodies (MSF, Misereor), which have come to rely on it. Today, the world spotlight has illumined the contribution by some Taiwanese organisations in structuring a new 
transnational health space, which includes "the people living with HIV/Aids, the health activists and the NGOs, the private sector and the extensive networks that they have created" 76 on both sides of the Strait and throughout the region.

Possible diplomatic exploitation?

In the context of what is commonly known as informal diplomacy (minjian) ${ }^{77}$, the advantages of which the Taiwanese government has been extolling for some years, particular emphasis is given to the NGOs and to the role they may play in improving Taiwan's status on the international scene. One is entitled to wonder if the Taiwanese government, given the public visibility of some Taiwanese NGOs, does not seek to use them-as it does the Medical Professional Alliance in Taiwan-to promote Taiwan's international status. In fact, in order to glean first-hand information about the Chinese health situation, health officials are reported to have asked a Taiwanese organisation to play some kind of "health spy" role on the Chinese side of the Strait. The organisation preferred to protect its autonomy and to pursue its work in China: it unhesitatingly rejected the proposition.

Another attempt at exploiting for diplomatic purposes the transnational work of the Taiwanese NGOs is the proposal by the former Health Minister Twu Shiing-Jer to set up the "Red Ribbon Foundation". Some of the associations' leaders have become uneasy about the interference by government ministers in their action programmes abroad. So far, despite such attempts, it would seem that the Taiwanese NGOs may be too attached to their autonomy to accept being used as tools by the diplomats.

One must accept that, when it comes to diseases such as HIV/Aids, Taiwan is not an island; some non-state health workers, especially in the NGOs, have progressively developed a response that is diversified and complementary to what the government has been doing-both at the national and at the transnational level. This nongovernmental mobilisation would never have been possible without the democratic process embarked upon in Taiwan in the late 1980s, a process that helped the Taiwanese NGOs to emerge, to make themselves heard and to act. Conversely, defending the rights of HIV-positive people-to work, to healthcare, to education and to accommodation-strengthens democracy. Putting it another way, democracy and the war against HIV/Aids in Taiwan are interactive, with reciprocal benefits.

The fact remains that, at the present time, the growing infection rate reminds the NGOs and also the health authorities that many challenges are still to be faced, especially those of discrimination against HIV-positive people and their stigmatisation, as well as young people's vulnerability to HIV/Aids.

71 Lastly, in the Asia-Pacific region, the response to HIV/Aids will determine, according to the latest joint report by UNAIDS and the Asian Development Bank, the future of the epidemic on a world scale ${ }^{78}$; in such conditions, the Taiwanese NGOs-despite the ostracising of Taiwan at the world level-have proved themselves to be active warriors in a transnational struggle.

Translated from the French original by Philip Liddell 


\section{NOTES}

1. UNAIDS, 2004 Report on the Global Aids Epidemic. Executive Summary, July 2004, p. 3

2. Ibid., p. 5

3. UNAIDS, Aids Epidemic Update, December 2004, p. 36

4. The Centre's website address is http://www.cdc.gov.tw/WebSite_En/index1024.htm

5. Which means an annual increase rate of more than $70 \%$.

6. CDC data, July $31^{\text {st }} 2005$

7. Proportionally four times less than, for instance, in France, where the proportion of HIV patients to the population as a whole is estimated at $0.16 \%$ (100,000 cases).

8. Lester M. Salamon, "The Rise of the Non-profit Sector", Foreign Affairs, Vol. 73, No. 4, July-August 1994, pp. 109-122.

9. Shelley Rigger, "Mobilisational authoritarianism and political opposition in Taiwan", in Garry Rodan (ed.), Political Oppositions in Industrialising Asia, London and New York, Routledge, 1996, pp. 301-322.

10. As opposed to "traditional NGOs" controlled by the state and the nationalist Kuomintang party (KMT), in Chen Jie, Foreign Policy of the New Taiwan. Pragmatic Diplomacy in Southeast Asia, Northampton, Edward Elgard, 2002, pp. 235-238.

11. On Lourdes Home and PRAA, see Vincent Rollet, "Obstacles, dynamism and challenges for Taiwanese NGOs in the fight against HIV/Aids", Face to Face. Another Look at Health (Internet edition) June 2005, ADES, UMR CNRS University of Bordeaux 2, http://www.ssd.u-bordeaux2.fr/faf/uk/last_ed/articles/rollet_uk.htm

12. While the tax authorities do require the NGOs to declare their budgets, nothing in the law obliges them publicly to disclose information about donations, government support or even their expenditure. Although some NGOs do seem to put such information on their websites, in the annual reports on their activities or in their monthly newsletters, quite often their financial situations are not made public, cf. Yu Yuan Kuan, Andy Kao, Marie-Claude Pelchat, "Governance, organisational effectiveness and the profit sector. Taiwan Report", 17th October 2003, p. 13, http:// www.tpic.org.tw/Reports/ShowReport.asp ? Report_ID=10.

13. http://www.unitedway.org.tw/

14. Yu Yuan Kuan, Andy Kao, Marie Claude Pelchat, "Governance, organisational effectiveness and the profit sector. Taiwan Report", in Taiwan Philanthropy Centre Information (TPIC), http://www.tpic.org.tw/Reports/ShowReport.asp?Report_ID=10, October 17th 2003, p. 2. See also Michael Hsiao, "Civil Society and Democracy in Taiwan: 1980-2004", presentation made during the International Symposium on Asia's New Democracies; Taiwan, The Philippines and South Korea Compared, $2^{\text {nd }}-3^{\text {rd }}$ September 2004, Academia Sinica, Taipei, Taiwan.

15. “Taiwan's NGOs need organized leadership", Taipei Times, September 26th 2000, p. 8; "The promises and pitfalls of NGOs", Taipei Times, June 16th 2001, p. 8.

16. Harmony Home Association was officially registered in 2003. Its leader and some of its volunteers have been working with people who are HIV-positive for more than fifteen years.

17. The Seventh National Conference on HIV/Aids was organised by the Taiwanese Department of Health in collaboration with HIV/AIDS Control \& Study Center of National Taiwan University (NTU); during the conference, some public health experts 
and Taiwanese activists sharply criticised the Department of Health for lack of initiative and lack of originality as regards prevention among the young people of Taiwan; the national health education system was also attacked as being inadequate. cf. "Anti-HIV efforts require revamping, experts say", Taipei Times, $20^{\text {th }}$ July 2004, p. 1. Since then, the CDC seems to have made an effort: "Taiwan's HIV situation no longer marginal issue on government's agenda", The China Post, digital edition, November 29th 2004.

18. The leader of one organisation related to us how she had asked a well-wisher, someone able to cry at will, to go up on the platform alongside a young HIV-positive patient who was explaining his situation, "to touch the young people's hearts".

19. Many association leaders acknowledge that, from their own personal experience, if the subject of HIV/Aids prevention is broached coldly it either frightens off youthful listeners or simply insulates them from the question, assuming that it does not affect them personally.

20. Interview with the leader of the Lofaa association, January 10th 2005, Taipei.

21. These are panels of material, designed in memory of people who have died of Aids. For an analysis of their meaning, and of their role in the fight against HIV/Aids in Taiwan, cf. Evelyne Micollier, "AIDS and Civil Society in Taiwan", in E. Micollier (ed.), Sexual Cultures in East Asia. The Social Construction of Sexuality and Sexual Risk in a Time of AIDS, London, Routledge, 2004, pp. 231-234.

22. $\mathrm{ABC}$ : Abstinence, Be faithful, Correct management of condoms. This is a prevention strategy that promotes abstinence and fidelity first and condoms last in the fight against HIV/Aids. Its defenders, such as the Ugandan President, Yoweri Museveni, (and his wife) assert that if today a country like Uganda has succeeded in substantially reversing the growth curve of HIV/Aids among its people (down from $21 \%$ in the 1980 s to $6 \%$ in 2003), it is entirely due to having organised national campaigns to persuade the Ugandan people that only abstinence and fidelity will fend off HIV/Aids. Museveni himself defended his strategy at the most recent International Conference on Aids in Bangkok in July 2004; but most activists do not consider it effective. They argue instead that promoting the use of condoms is the best strategy for combating the spread of HIV, especially in countries where the rate of infection through prostitution is high.

23. Interview with Lin Yi-Hui, leader of PRAA, August $26^{\text {th }} 2004$, Taipei.

24. This plan was presented on January 29th 2003 by the US President, George Bush, and promises US $\$ 15$ billion in aid, over five years, to help fight Aids: www.whitehouse.gov/news/releases/2003/01/20030129-1.html/

25. A study carried out in 2002 showed that $43 \%$ of medical staff were refusing to treat HIV-positive patients.

26. "Aizi baobao manyue. Mama qiangjie shangbao" (A month-old infant who is HIVpositive. A thieving mother on the front page), Lianhe wanbao (United Evening News), September 29th 2004, p. 6.

27. Similarly, for the second time in a year, a shelter run by Harmony Home, in the district of Wenshan, is threatened with closure because of strong opposition from the neighbourhood committee, which "refuses to live in the fear that, one day, one of these HIV-positive people will stab a local resident with a syringe or be a negative influence on the children", cf. "HIV/AIDS sufferers face eviction", Taipei Times, July 11th 2005, p. 2. On this subject see Evelyne Micollier, "Phenomena of stigmatisation in a Chinese world confronted by HIV/Aids: towards a collaboration between official reaction and civil society", in L'approche culturelle de la prévention et du traitement du VIH/Sida: 
stigmatisation et discrimination, Paris, Publications de l'Unesco, Etudes et rapports, No. 20, p. 44.

28. CDC, AIDS Prevention and Control Act, December 17th 1990, in http:// www.cdc.gov.tw/WebSite_En/index1024.htm

29. CDC, Communicable Disease Control Act, December 6th 1944, in http:// www.cdc.gov.tw/WebSite_En/index102 4.htm

30. "Xuexiao jushou aizihuan" (A School Turns Away an Aids Patient), Minsheng bao, April 9th 2004, p. A15.

31. CDC, AIDS Prevention and Control Act, December 17th 1990, p. 6.

32. Even a celebrity such as the basket-ball player Magic Johnson was not exempted. On this subject: Hsu Mei-Ling, Lin Wen-Chi, Wu Tsui-Sung, "Representations of 'Us' and 'Others' in the AIDS News Discourse: A Taiwanese Experience”, in E. Micollier (ed.), 2004, op. cit., p. 205.

33. "HIV deportations reconsidered", Taipei Times, November 9th 2004, p. 2.

34. Yi-Hui Lin, Qiantan Taiwan aizi ganranzhi zhengqu qiben renquan de kunnan (The fight by people living with HIV/Aids for their rights, in Taiwan). Contribution to the $7^{\text {th }}$ International Conference on HIV/Aids, Taipei, July 18th-19th 2004.

35. James Knight, "Models of Health", in John Germov, Second Opinion. An Introduction to Health Sociology, Oxford University Press, Oxford, 2000, pp. 147-150.

36. http://aids.cdc.gov.tw/home.asp

37. Philippe Ryfman, Les ONG, Paris, La Découverte, 2004, p. 68.

38. Interview with Wang Chung-Chi, head of Living with Hope, December 2nd 2004, Taipei.

39. Dennis R.Young, "Alternative Models of Government-Nonprofit Sector Relations: Theoretical and International Perspectives", Nonprofit and Voluntary Sector Quarterly, Vol. 29, No. 1, March 2000, pp. 149-172.

40. Ibid, p. 150.

41. Ibid, p. 150.

42. Interview with Twu Shiing-Jer, former Department of Health director and head of the Taiwan AIDS Association, November 19th 2004, Taipei.

43. Evelyne Micollier, "Emergence de la société civile à Taiwan, vers une gestion collective des problèmes de santé" in Christine Chaîgne, Christine Paix, Chantal Zheng, (eds.), Taiwan: Enquête sur une identité, Paris, Karthala, 1999, pp. 309-331.

44. Dennis R. Young, "Alternative Models of Government-Nonprofit Sector Relations: Theoretical and International Perspectives", Nonprofit and Voluntary Sector Quarterly, Vol. 29, No. 1, March 2000, p. 150.

45. Interview with Lin Yi-Hui, head of PRAA, August 26th 2004, Taipei.

46. PRAA, Jianli zhengxiang aizi fangzhi zhengce gongzuofang. Yi ge minjian de zizhu shengyin (Workshop for developing an improved Aids prevention policy. The independent voice of the people), Report, July 2004, $29 \mathrm{pp}$.

47. Interview with Sister Teresa Hsieh, head of Lourdes Home, August 4th 2004, Taipei. 48. "HIV: free prenatal tests available from $1^{\text {st }}$ January", Taiwan Info, online edition, December 2nd 2004. We should note that the most recent advertising campaign in Taiwan for promoting condoms, mounted by the Control Centre for Sexually Transmitted Diseases (STD) in Taipei, was banned. The poster showed a woman in nun's habit saying: "Although I don't use condoms, I know [what they are]!". Religious groups had the poster banned and demanded an apology from the 
health authorities, cf. "Condom nun sparks outrage", Taipei Times, August 25th 2005, p. 3.

49. Vincent Rollet, "Mobilisation composite contre le sida", Taiwan Aujourd'hui, Vol. XXII, No. 1, January 2005, pp. 34-37.

50. "HIV deportations reconsidered", Taipei Times, November 9th 2004, p. 2.

51. AIDS Action is a national partnership of American associations fighting HIV/Aids, local health departments and health training establishments. http:// www.aidsaction.org

52. Thomas Risse-Kappen defines them as "regular interactions across national boundaries when at least one actor is a non-state agent or does not operate on behalf of a national government as an intergovernmental organization", in Thomas RisseKappen (ed.), Bringing transnational relations back in. Non State actors, domestic structures and international institutions, Cambridge, Cambridge University Press, 1995, p. 3.

53. Patrick Kenis, "Why do Community-based AIDS Organizations co-ordinate at the Global Level?", in K Ronit, V Schneider (eds.), Private Organizations in Global Politics, New York, London, Routledge, 2000, p. 141.

54. Bernard Eccleston, "Does North-South Collaboration Enhance NGO Influence on Deforestation Policies in Malaysia and Indonesia", Journal of Commonwealth and Comparative Politics, Vol. 34, No. 1, 1996, p. 69.

55. Chen Jie, Foreign Policy of the New Taiwan. Pragmatic Diplomacy in Southeast Asia, Northampton, Edward Elgard, 2002, p. 248.

56. Ibid, p. 249.

57. Chen Jie, "Burgeoning Transnationalism of Taiwan's Social Movement NGOs", Journal of Contemporary China, Vol. 10, No. 29, 2001, pp. 613-644.

58. By "international health space", we mean the whole range of intergovernmental relations and the international regulations and agreements relating to health questions, which have for a long time been the traditional methods for fighting infectious diseases.

59. Christer Jönsson, Peter Söderholm, "IGO-NGO Relations and HIV/AIDS: Innovation or Stalemate?", in T Weiss, L Gordenker (eds.), NGOs, the UN and Global Governance, London, Lynne Rienner, 1996, p. 122.

60. http://healthtaiwan.doh.gov.tw/whowbs/article_post/post_userviewE_axtpg.jsp? ID_NO=231

61. The Seven Sisters or the Coalition of Asia-Pacific Regional Networks on HIV/AIDS combines: APCASO (Asia/Pacific Council of AIDS Service Organizations), ASAP (AIDS Society of Asia and the Pacific), CARAM-Asia (Coordination of Action Research on AIDS and Mobility in Asia), AHRN (Asian Harm Reduction Network), APR (Asia Pacific Rainbow), APN+ (Asia-Pacific Network of People Living with HIV/AIDS) et APNSW (AsiaPacific Network of Sex Workers).

62. The other site being the Taipei Veterans' General Hospital.

63. In parallel with Internet access, there is a general understanding of the networks' online texts in English among the Taiwanese associations, who each have at least one member able to read them. Thereafter, translating the texts into Chinese and posting them online does take a little while.

64. Treat Asia, Treat Asia Site Profile:AIDS Prevention and Research Centre, National Yang-Ming University, Taipei, Taiwan, available on www.amfar.org/cgi-bin/iowa/asia/ news/index.html?record=51. 
65. The petition of December 14th 2001 is available on http://archives.healthdev.net/ sea-aids/msg00103.html, and that of August 24th 2002 on http://archives.hst.org.za/saaids/msg00388.html.

66. The other delegate was the International Affairs Director of the Gender/Sexuality Rights Association Taiwan (GSRAT).

67. Treat Asia includes five Chinese centres for research into HIV/Aids; APN+ has a Hong Kong representative; and the other networks belonging to the Seven Sisters have Chinese members too.

68. Interview with Nicole Yang, head of Harmony Home Association, November 30th 2004, Taipei. Interview with Wang Chung-Chi, head of Living with Hope, December 2nd 2004, Taipei.

69. Interview with Wang Chung-Chi, head of Living with Hope, December 2nd 2004, Taipei.

70. "Taiwan helping Malawi cope with AIDS epidemic", Taipei Times, April 19th 2005, p. 2.

71. Elisabeth Rosenthal, "Silent Plague: A special report; "Deadly Shadow Darkens Remote Chinese Village", New York Times, May 28th 2001, p.1, E Rosenthal, "In Rural China, a Steep Price Of Poverty: Dying of AIDS", October 28th 2000, http:// query.nytimes.com/gst/health/article-printpage.html? res=9A0CEED\%20B1630F93BA15753C1A9669C8B63

72. Sister Teresa Hsieh, "Zhongguo Tianzhu Jiaohui kaizhan aizibing fuwu”, (The Church of China develops Aids services), Jiaoyou shenghuo zhoukan, October 31st 2004. 73. Misereor worked for a long time in Taiwan on a variety of health and social projects, before being able to extend its activities to China. Interview with a former member of Misereor, Peking, May 2005.

74. Vincent Rollet, Le rôle des ONG sanitaires internationales face au VIH/Sida en Chine, memoir for DEA de Relations Internationales, Institut d'études politiques de Paris, 2002, 143 pp.

75. "County shuts down private Aids orphanage", South China Morning Post, February 3rd 2004, p. A6. In this article, reference is made-without any further detail about which country was involved-to the "foreign connections" that the head of the orphanage was keeping up.

76. Ilona Kickbusch, "Global Health Governance: Some Theoretical Considerations on the New Political Space", in Lee K. (ed.), Health Impacts of Globalisation, New York, Palgrave, 2003, pp. 192-203.

77. What Taipei calls the minjian tuanti resembles the term "NGO" commonly used in the discourse of international politics. Chen Jie, Foreign Policy of the New Taiwan. Pragmatic Diplomacy in Southeast Asia, Northampton, Edward Elgard, 2002, p. 256. 78. ADB, UNAIDS, Asia Pacific's Opportunity: Investing to avert an HIV/AIDS Crisis, July 2004, p. 1. 


\section{RÉSUMÉS}

In Taiwan, as in the rest of the world, the health authorities have been confronted during the past decade by an inexorably growing number of cases of HIV/Aids. Local NGOs have committed themselves, in partnership with the authorities, to a national and regional response. This article will look at the methods used by these non-state actors, at the reasoning behind their actions and at the interactive and transnational character of their struggle. 